\title{
Research on Influence of the Congruence of Self-Image and Brand Image on Consumers' Citizenship Behavior
}

\author{
Wanling Huang, Ming Chen \\ School of Business Management, South China University of Technology, Guangzhou, China \\ Email: wanling_bb@sina.com
}

How to cite this paper: Huang, W.L. and Chen, M. (2018) Research on Influence of the Congruence of Self-Image and Brand Image on Consumers' Citizenship Behavior. Open Journal of Business and Management, 6, 193-201.

https://doi.org/10.4236/ojbm.2018.61013

Received: December 20, 2017

Accepted: January 27, 2018

Published: January 30, 2018

Copyright $\odot 2018$ by authors and Scientific Research Publishing Inc. This work is licensed under the Creative Commons Attribution International License (CC BY 4.0).

http://creativecommons.org/licenses/by/4.0/

\begin{abstract}
Customer citizenship behavior is a new concept in the field of customer behavior research. It is a valuable and constructive behavior of consumers who are willing to do for the brand out of their roles, which makes the enterprise competitive due to low cost or even zero cost. Therefore, it has gradually attracted widespread concern from domestic and foreign researchers and practitioners in marketing. This paper studies the antecedent variables of consumer citizenship behavior. The connection of self and brand acts as the mediator between the congruence of consumer's self-image as well as brand image and consumer citizenship behavior. Specifically speaking, neither the consumer's self-image nor brand image directly affects his/her citizenship behavior but affected by the mediate role of self-brand connection. Only when the consumer voluntarily connects himself/herself with the brand and form high-quality consumer-brand relationship, will consumers voluntarily engage in valuable and constructive behaviors for the brands. In this way, the consumer citizenship behavior forms.
\end{abstract}

\section{Keywords}

Consumer Citizenship Behavior, Self-Brand Connection, Self-Image and Brand Image

\section{Introduction}

In Internet era, the growth and prosperity of the retail industry have diversified the choices of consumers. The numerous and jumbled choices give consumers overloaded information, bringing more decision-making difficulties and potential risks. Therefore, in order to simplify the purchase decision, customers are more inclined to make the purchase choice with the help of official discussion areas, virtual community, network forums, offline recommendation, and public 
praise. Consumers recommend brands spontaneously through good word of mouth; share their own experience to help other customers search, buy and use products, actively give feedbacks as well as useful advice to enterprises and so on. Such behavior is called consumer citizenship behavior. Customer citizenship behavior is a new concept in the field of customer behavior research. It is a valuable and constructive behavior of consumers who are willing to do for the brand out of their roles, which makes the enterprise competitive due to low cost or even zero cost. Therefore, it has gradually attracted widespread concern from domestic and foreign researchers and practitioners in marketing. Consumer citizenship behavior can not only help other consumers evade consumption risk and make purchase decision quickly, but also contribute to the brand's propaganda and promotion [1].

Although consumer citizenship behavior plays an important role in enhancing brand influence and competitiveness, many studies just provide a rough idea on the antecedent course of consumer citizenship behavior generally based on the assumption that "consumers are part-time employees of enterprises". The discussion of the antecedent course of consumer citizenship behavior draws heavily on the research on the antecedent of employee organizational citizenship behavior. However, unlike employees, consumers are not likely to be civic for the organization due to potential job or salary enhancements. Therefore, consumer citizenship behavior has different antecedents from organizational citizenship behavior and it may be more affected by the relationship between consumers and brands.

Consumer citizenship behavior is mainly manifested in the consumer's recommendation behavior, help behavior and feedback behavior and so on, spreading the good public praise of brands. Thus, consumer citizenship behavior will arise only when consumers are willing to associate themselves with the brand and take the brand as part of ego. Wang Consumer's self-brand connection will have a series of positive impacts on brand relations and promote brand attitudes [1] [2], leaving consumers with brand attachment and love in the emotional dimension [3]. Consumer's emotional attachment has a significant positive effect on consumer citizenship behavior [4]. In the behavioral intention dimension, self-brand connection is conducive to the formation of brand commitment, which can positively drive consumer citizenship behavior [1]. When a brand becomes a symbol and brand image helps to strengthen the consumer self-concept, it will have a significant impact on brand loyalty, which means when consumers connect themselves with brand, they will be loyal to the brand [5]. Found that when a restaurant's brand personality meets the needs of consumer self-experience [6], it can not only generate brand love and brand loyalty, but also enhance the consumer's word-of-mouth behavior, indicating that the self-brand connection impacts the willingness to word-of-mouth. Emotional attachment and brand commitment have significant positive influences on consumer citizenship behavior, and loyalty and word-of-mouth are the dimensions of consumer citizenship behavior. Therefore, the self-brand connection may be one 
of the influential factors of consumer citizenship behavior.

The theory of self-consistency holds that people tend to behave in a way that maintains and promotes one's own self-concept [2]. When consumers make purchasing choices, they tend to choose brands that match their self-image, for which can convey their self-image to other by brand image. Therefore, when the brand image is consistent with consumer' self-image, consumers will be more willing to be connected with the brand [7]. Consumers integrate the brand image into the self-concept by establishing a psychological connection with the brand, forming a high quality relationship with the brand.

Based on the discussion above, this study tries to construct the mechanism model of the influence of consumer self-image and brand image consistency on consumer citizenship behavior and to explore the antecedents of consumer citizenship behavior, so as to provide theoretical and practical application in this field.

\section{Literature Review}

\subsection{Self-Image and Brand Image Consistency Self-Brand Connection}

The self-image of consumers is the individual's perception and feeling of the whole as an object [8]. It is the personal character, identity role, illusion, relationship and the symbols used by individuals for self-understanding and self-creation. It is also a combination of individual perceptions of various aspects of one's own, including personal attitudes and understandings of personality, abilities, and interests, the relationship between individuals and other people, and the evaluation of individual real life.

The domestic and foreign scholars' researches on brand image are mainly based on the associational brand image of consumers and the brand image model subject to the corporate brand identity strategy. This paper studies the impact of consumer-perceived consistency between brand image and self-image on consumer citizenship behavior. The model chosen is based on the brand image associated by consumers. At present, most of researches on brand image are based on consumers' psychological cognition. Many scholars believe that the brand image reflects the consumer's overall perception, feeling and attitude towards the brand. Aaker and Keller argue that a brand image is a collection of meaningful brand associations that together form the overall consumer impression of the brand, called the brand image [9].

Many researches have studied from a single perspective of brands and consumers, believing that the presence of a brand image gives consumers extra values beyond the entity and solving the problem of product homogeneity for marketing. In this sense, the shaping of brand image is an important foundation for enterprise brand management.

However, with the advent of the market information and network era, more and more enterprises begin to shift their attention from single brand building to 
associations of brand image with consumer self-image and study brand building from the perspective of both brands and consumers.

Self-brand connections (SBCs) refer to the extent to which consumers use brands to build, reinforce, and express individual or social self [2]. When consumers use brand to convey self-concept to others, the connection between the consumer and the brand is established [10]. Through the psychological link with the brand, consumers assimilate the brand image into the self-concept, willing to form the high quality of relationships similar to interpersonal relationship between themselves and the brand.

\subsection{Consumer Citizenship Behavior}

The concept of consumer citizenship behavior extends from the area of organizational citizenship behavior. Gruen was the first to use the concept of "citizenship" to describe consumer behavior in enterprise relationship marketing. Based on the traditional definition of "organizational citizenship behavior", Groth was the first to formally propose the concept of "consumer citizenship behavior", which is defined as "consumer's voluntary behavior" that is not necessary for the production or successful delivery of services, but is beneficial for the entire service organization on the whole. For example, consumers recommend products or services to friends and relatives, propose improvements or enhance services to the enterprises, actively cooperate with the market research activities of enterprises, and leave favorable comments for online shop products in online shopping activities. Similar concepts include consumer role behaviors, consumer spontaneous behavior [11], consumer organizational citizenship behavior, and consumer involvement. Although different scholars define consumer citizenship behavior differently, the substance of the content is basically the same. There are three important characteristics of consumer citizenship behavior: 1) Voluntary. Consumer citizenship behavior is not mandatory but voluntary; 2) Positive. Consumer citizenship behavior positively impacts on enterprises, employees and even consumers; 3) Non-character. Consumer citizenship behavior is not required by the consumer's role, or a necessary act of producing or delivering services, which is also the most important feature of consumer citizenship [12].

\subsubsection{Antecedent Causes of Consumer Citizenship Behavior}

Since the concept of consumer citizenship behavior was put forward, the antecedents of consumer citizenship behavior have been widely concerned by scholars. From the perspective of offline consumer citizenship behavior, relevant variables such as trust, relationship commitment, perceived enterprise support, perceived organizational justice, loyalty tendencies and so on, have been proved to be the antecedents of consumer citizenship behavior, which largely draws on organizational citizenship behaviors related research, without considering the difference between consumers and employees in the role and the relationship with the enterprise [13]. The antecedent causes have also been analyzed from the perspective of consumers, such as the impact of consumer participation on consumer citizenship behavior, and from the enterprise perspective such as corpo- 
rate reputation and corporate social responsibility.

The antecedents of online consumer citizenship behavior also focus on the impact of quality of the relationship between consumers and enterprises on consumer citizenship behavior, such as satisfaction, community commitment, service fairness and trust. There are some different antecedent variables for offline consumer citizenship behavior, such as virtual brand community interaction, consumer acceptance, network reciprocity and other factors.

\subsubsection{Consumer Citizenship Behavior Dimension Division}

In the dimension Division, Bettencourt proposes three dimensions of customer citizenship: loyalty, cooperation and participation [11]. This kind of division has been adopted by subsequent researchers for many times.

Groth was the first person to carry out an empirical study on consumer citizenship behaviors in the B2C Internet environment [14], and has summarized three dimensions of consumer citizenship behaviors: 1) Recommendation behavior. Recommend company's products or services to family members, colleagues, or anyone interested in; 2) Feedback behavior. For example, participate in the investigation of enterprises to provide helpful advice; 3) Help behavior. For example, help other consumers search, buy products and guide them how to use the service properly.

Based on the three dimensions of Bettencourt, Bove proposed eight dimensions of consumer citizenship behaviors: word-of-mouth communication, relationship display, participation in business activities, benevolence, flexibility, suggestions for service improvement, feedback and influence on other consumers. On the basis of this, Jiang classifies the behavior of virtual brand community citizens into five dimensions: positive word of mouth, active participation, helping others, feedback and maintaining order. After further analysis of these dimensions, actually they are a kind of moral behavior, for example, online brand community citizenship behavior maintains the interests of the brand community itself and members of the community. From the perspective of beneficiaries, group citizenship behaviors can be divided into behaviors conducive to brand community (such as word of mouth to the community) and behaviors in favor of community members (such as answer questions for the community members).

With different perspectives and emphases of researches, different scholars have different definitions for the dimensions of customer citizenship behavior, but most of them overlap each other. The three-dimensional division of consumer Citizenship behavior is more representative. Although Groth's viewpoint originates from the empirical analysis in online shopping scenarios, the rationality of this dimension division is also empirically supported in education industry and fitness industry.

\subsection{Self-Brand Connection and Consumer Citizenship Behavior}

From the existing studies on the division of the dimensions of consumer citizenship, we can see that consumer citizenship mainly manifests as positive publicity, recommendation of friends and relatives, positive service improvement 
and so on. Thus, consumer citizenship behavior will arise only when consumers are willing to associate themselves with the brand and take the brand as part of ego. Consumer's self-brand connection will have a series of positive impacts on brand relations and promote brand attitudes [1], leaving consumers with brand attachment and love in the emotional dimension [3]. Consumer's emotional attachment has a significant positive effect on consumer citizenship behavior [4]. In the behavioral intention dimension, self-brand connection is conducive to the formation of brand commitment, which can positively drive consumer citizenship behavior [1]. When a brand becomes a symbol and brand image helps to strengthen the consumer self-concept, it will have a significant impact on brand loyalty, which means when consumers connect themselves with brand, they will be loyal to the brand. When a restaurant's brand personality meets the needs of consumer self-experience, it can not only generate brand love and brand loyalty [6], but also enhance the consumer's word-of-mouth behavior, indicating that the self-brand connection impacts the willingness to word-of-mouth. Emotional attachment and brand commitment have significant positive influences on consumer citizenship behavior, and loyalty and word-of-mouth are the dimensions of consumer citizenship behavior. Therefore, the self-brand connection may be one of the influential factors of consumer citizenship behavior.

According to the mentioned literature review above, we can see that a lot of literatures have studied the antecedents of consumer citizen behavior generally based on the assumption that "consumers are part-time employees of enterprises", and the discussion on the antecedents of consumer citizenship behavior draws heavily on the research of the antecedent of employee organizational citizenship behavior. Unlike employees, consumers are not likely to be civic for the organization due to potential job or salary enhancements. Therefore, future research should jump out of the shackles of employee organizational citizenship behavior and investigate the reasons why customer citizenship behavior differs from employee organizational citizenship behavior.

\section{Models and Assumptions}

Based on the research above, this paper proposes a model of the mechanism of how consumer's self-image and brand image consistency impacts consumer behavior, as shown in Figure 1:

The theory of self-consistency holds that people tend to behave in a way that maintains and promotes one's own self-concept [2]. When consumers make purchasing choices, they tend to choose brands that match their self-image, for which can convey their self-image to other by brand image. Therefore, when the brand image is consistent with consumer' self-image, consumers will be more willing to be connected with the brand. Based on this, the following assumption is proposed:

H1: The consistency of self-image and brand image has a significant positive impact on consumers "self-brand connection". 


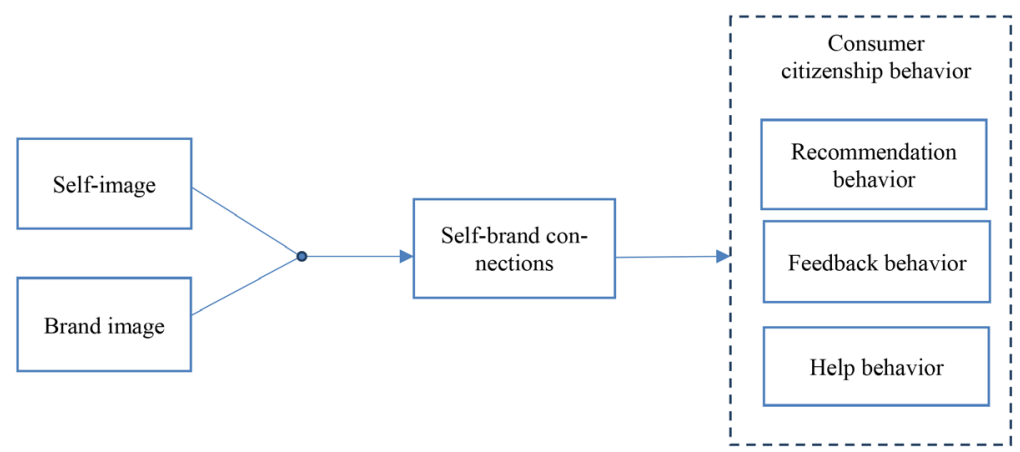

Figure 1. Influence of the congruence of self-Image and brand image on consumers' citizenship behavior.

The theory of self-consistency holds that people tend to behave in a way that maintains and promotes one's own self-concept. When consumers make purchasing choices, they tend to choose brands that match their self-image, for which can convey their self-image to other by brand image. Therefore, when the brand image is consistent with consumer' self-image, consumers will be more willing to be connected with the brand. Based on this, the following assumption is proposed:

H1: The consistency of self-image and brand image has a significant positive impact on consumers "self-brand connection".

\section{Contributions and Limitation}

As for the research on the consistency of consumer self-image and brand image, the domestic scholars mainly focus on the purchase behavior, brand loyalty and brand preference. However, the research on the influence of consistency concept on consumer citizenship behavior is lacking. This study systematically summarizes the relationship between consumer self-image and brand image consistency and consumer citizenship behavior, expounds the positive influence of self-concept consistency on consumer's self-brand connection and thus affects consumer citizenship behavior, which can provide reference for further study on consumer's behavior antecedents. Based on the research of literature, this paper establishes a research model to understand the influence of the consistency of consumer self-image and brand image on the behavior of consumer citizens. When consumers' self-image is consistent with brand image, consumers will be more willing to link with the brand and be in favor of the brand from the bottom of their heart, generating more constructive behaviors that are beneficial to the brand, such as word-of-mouth recommendation, active feedback behavior of service improvement, behavior of helping other consumers and so on. This paper proposes that consumer self-brand connection plays an intermediary role between the consistency of self-image as well as brand image and consumer's citizenship behavior. That is to say, neither the consumer's self-image nor brand image directly affects his/her citizenship behavior but affected by the mediate role of self-brand connection. Only when the consumer voluntarily connects 
himself/herself with the brand and form high-quality consumer-brand relationship, will consumers voluntarily engage in valuable and constructive behaviors for the brands. In this way, the consumer citizenship behavior forms.

There are some limitations in this study. First there are many other factors affecting consumer citizen behavior besides the consistency of consumer's self-image and brand image. Therefore, we can study the influence of other factors on consumer citizen behavior in the future. Second, the self-image of consumers is divided into real self, ideal self and social self. Some scholars have studied the impact of ideal self-concept/real self-concept and brand personality on brand preference. Consumer self-concept Consistency has a different impact on brand purchases in private and public contexts, and brand purchases are based on brand relationships. Considering the complexity of measurement, this study does not distinguish between true self and ideal self-concept at the same time. Subsequent research can study the impact on consumer behavior from the different dimensions of consumer self-image. Third, many studies show that people's consumption behaviors are closely related to their lifestyles and cultural forms. For example, some symbols may have different symbolic meanings under different cultural backgrounds. Therefore, in the future, we need to consider whether there is difference between consumer image and brand personality in consumer citizenship under different cultural backgrounds.

\section{References}

[1] Sun, N.J. and Guo, G.Q. (2016) Customer Commitment, Self-Enhancement and Customer Citizenship Behavior: Driving Mechanism and Moderating Effect from the Perspective of Social Exchange Theory. Management Review, 28, 187-197.

[2] Wang, C.Y. (2013) The Connotation, Mechanism and Effects of Self-Brand Connections. Advances in Psychological Science, 21, 922-933.

https://doi.org/10.3724/SP.J.1042.2013.00922

[3] Hwang, J. and Kandampully, J. (2012) The Role of Emotional Aspects in Younger Consumer-Brand Relationships. Journal of Product \& Brand Management, 21, 98-108. https://doi.org/10.1108/10610421211215517

[4] He, M.-X. and Luo, J.-H. (2016) The Mechanisms of Corporate Reputation Impact on Consumer Emotion Attachment and Customer Citizenship Behavior. China Business and Market, 30, 108-114.

[5] Guthrie, M., Kim, H. and Jung, J. (2008) The Effects of Facial Image and Cosmetic Usage on Perceptions of Brand Personality. Journal of Fashion Marketing \& Management, 12, 164-181. https://doi.org/10.1108/13612020810874863

[6] Kim, D., Magnini, V.P. and Singal, M. (2011) The Effects of Customers' Perceptions of Brand Personality in Casual Theme Restaurants. International Journal of Hospitality Management, 30, 448-458. https://doi.org/10.1016/j.ijhm.2010.09.008

[7] Cheng, S.Y.Y., White, T.B. and Lan, N.C. (2012) The Effects of Self-Brand Connections on Responses to Brand Failure: A New Look at the Consumer-Brand Relationship. Journal of Consumer Psychology, 22, 280-288.

https://doi.org/10.1016/j.jcps.2011.05.005

[8] Sirgy, M.J. (1982) Self-Concept in Consumer Behavior: A Critical Review. Journal of Consumer Research, 9, 287-300. https://doi.org/10.1086/208924 
[9] Aaker, J.L. (1997) Dimensions of Brand Personality. Journal of Marketing Research, 34, 347-356. https://doi.org/10.2307/3151897

[10] Yuan, Y., Liu, L. and Du, Q.L. (2016) A Study on the Influence of Brand Stories on Consumers' Self-Brand Connection. Consumer Economics, No. 6, 85-90.

[11] Bettencourt, L.A. (1997) Customer Voluntary Performance: Customers as Partners in Service Delivery. Journal of Retailing, 73, 383-406. https://doi.org/10.1016/S0022-4359(97)90024-5

[12] Huang, W.Y. and Lin, X.J. (2013) Review and Prospect of Research on Customer Citizenship Behavior. Marketing Research, 2, 31-36.

[13] Zhang, Y.H. and Dong, D.H. (2013) Customer Citizenship Behavior: Review and Prospect. Contemporary Economy \& Management, 35, 9-14.

[14] Groth, M. (2001) Managing Service Delivery on the Internet: Facilitating Customers' Coproduction and Citizenship Behaviors in Service Organizations. Atmospheric Environment, 35, 5923-5933. 